\section{Comparison of Intracanopy Light-emitting Diode Towers and Overhead High-pressure Sodium Lamps for Supplemental Lighting of Greenhouse-grown Tomatoes}

\author{
Celina Gómez ${ }^{1,4}$, Robert C. Morrow ${ }^{2}$, C. Michael Bourget ${ }^{2}$, \\ Gioia D. Massa ${ }^{3}$, and Cary A. Mitchell ${ }^{1,5}$
}

ADDITIONAL INDEX WORDs. controlled environments, high-wire tomato, LED, Solanum lycopersicum, solid-state lighting, vertical lighting

SUMMARY. Electric supplemental lighting can account for a significant proportion of total greenhouse energy costs. Thus, the objectives of this study were to compare high-wire tomato (Solanum lycopersicum) production with and without supplemental lighting and to evaluate two different lighting positions + light sources [traditional high-pressure sodium (HPS) overhead lighting (OHL) lamps vs. lightemitting diode (LED) intracanopy lighting (ICL) towers] on several production and energy-consumption parameters for two commercial tomato cultivars. Results indicated that regardless of the lighting position + source, supplemental lighting induced early fruit production and increased node number, fruit number (FN), and total fruit fresh weight (FW) for both cultivars compared with unsupplemented controls for a winter-to-summer production period. Furthermore, no productivity differences were measured between the two supplemental lighting treatments. The energy-consumption metrics indicated that the electrical conversion efficiency for light-emitting intracanopy lighting (LED-ICL) into fruit biomass was $75 \%$ higher than that for HPS-OHL. Thus, the lighting cost per average fruit grown under the HPS-OHL lamps was $403 \%$ more than that of using LED-ICL towers. Although no increase in yield was measured using LED-ICL, significant energy savings for lighting occurred without compromising fruit yield.

$\mathrm{T}$ he U.S. greenhouse vegetable industry consists of many small, family-run operations and a few large facilities (Greer and Diver, 2000). Large greenhouse operations typically are located in the southwestern and western United States, where climate enables profitable production during winter, when vegetable prices are highest (Cook and Calvin, 2005). Nevertheless, several greenhouse facilities are also located in light-limited northern climates (low light intensities and short days), where optimal yield and quality

The research was funded in part by NIFA SCRI grant 2010-51181-21369

Assistance from Judy Santini, Chieri Kubota, Yiwei Jiang, Roberto Lopez, Mark Kroggel, Rob Eddy, Dan Hann, Eric Whitehead, Michael Dzakovich, Lucie Poulet, Cannon Cheng, and Jamie L. Ortman is gratefully acknowledged. Thanks also to MGS Horticulture for Biocontrol support, Syndicate Sales for growth media, and DeRuiter Seeds.

${ }^{1}$ Department of Horticulture and Landscape Architecture, Purdue University, West Lafayette, IN 47907

${ }^{2}$ Orbital Technologies Corporation, 1212 Fourier Drive, Madison, WI 5371

${ }^{3}$ Surface Systems Division, Mail Code NE-S-1, Kennedy Space Center, FL 32899

${ }^{4}$ Graduate Student

${ }^{5}$ Corresponding author. E-mail: cmitchel@purdue.edu. of vegetables can be achieved only by using supplemental lighting (Dorais et al., 1991; McAvoy and Janes, 1984; Rodriguez and Lambeth, 1975; Tibbitts et al., 1987). However, the use of supplemental lighting represents an expense to greenhouse vegetable production. Currently, energy is second only to labor as the most expensive indirect cost of production (Frantz et al., 2010). Thus, the greenhouse industry is interested in costeffective, energy-efficient sources of supplemental photosynthetic light to sustain steady supplies of high-quality produce during the off-season.

Most greenhouse growers who use supplemental lighting rely on overhead high-pressure sodium lamps because of their capability to deliver adequate photosynthetically active radiation $(P A R)$. Furthermore, HPS lamps are $\approx 25 \%$ efficient, and the waste thermal energy can be used to increase ambient greenhouse and plant temperature. Brault et al. (1989) estimated that, in northern climates, the heat emitted from HPS lamps provided between $25 \%$ and $41 \%$ of the heating requirements for a greenhouse operation. Thus, heat generation is sometimes considered a useful by-product of HPS lamp operation. On the other hand, HPS lamps have a high life-cycle cost, an intense environmental impact, and an orange-biased, red-and-bluedeficient emission spectrum (Nelson, 2012). These lamps typically require reflectors to direct the light from the lamps onto crops, thereby providing satisfactory light distribution and efficiency, but also blocking sunlight from reaching the crops. Their significant thermal output often requires a glass barrier, cooling, and considerable separation distance between plants and lamps to avoid tissue scorching (Cathey and Campbell, 1977). Like most available light sources, HPS lamps were originally designed for human use. However, HPS lamps have been widely adapted for greenhouse supplemental lighting because they currently are the most economically viable massproduced light source available that provides an adequate spectrum for plant growth.

LighT-EMITTING DiODEs. Lightemitting diodes are a promising supplemental lighting technology for the greenhouse industry as they surpass in many aspects capabilities of commercially available lamps commonly used in horticulture (Morrow, 2008). As described by Bourget (2008), LEDs are robust, solid-state semiconductor devices that can emit narrow-spectrum light to maximize

\begin{tabular}{llll}
\hline $\begin{array}{l}\text { Units } \\
\begin{array}{l}\text { To convert U.S. to SI, } \\
\text { multiply by }\end{array}\end{array}$ & U.S. unit & SI unit & $\begin{array}{l}\text { To convert SI to U.S., } \\
\text { multiply by }\end{array}$ \\
\hline 0.3048 & $\mathrm{ft}$ & $\mathrm{m}$ & 3.2808 \\
0.0929 & $\mathrm{ft}^{2}$ & $\mathrm{~m}^{2}$ & 10.7639 \\
2.54 & inch $(\mathrm{es})$ & $\mathrm{cm}$ & 0.3937 \\
0.0254 & $\mathrm{mil}$ & $\mathrm{mm}$ & 39.3701 \\
28.3495 & $\mathrm{oz}$ & $\mathrm{g}$ & 0.0353 \\
1 & $\mathrm{ppm}$ & $\mathrm{mg} \cdot \mathrm{L}^{-1}$ & 1 \\
0.001 & $\mathrm{ppm}$ & $\mathrm{mL} \cdot \mathrm{L}^{-1}$ & 1000 \\
$\left({ }^{\circ} \mathrm{F}-32\right) \div 1.8$ & ${ }^{\circ} \mathrm{F}$ & ${ }^{\circ} \mathrm{C}$ & $\left({ }^{\circ} \mathrm{C} \times 1.8\right)+32$ \\
& & &
\end{tabular}


photosynthetic quantum efficiency for specific crop species. In 2008, LEDs were as electrically efficient as fluorescent lamps and slightly less efficient than HPS lamps at converting electrical energy to light (Bourget, 2008 ). As of 2012 , blue and red LEDs are up to $50 \%$ and $38 \%$ efficient, respectively (Philips Lumileds Lighting Co., 2012). Unlike traditional high-intensity discharge (HID) light sources used in commercial greenhouses today, the relative coolness to the touch of LED photonemitting surfaces allows them to operate in close proximity to plant tissue without overheating or scorching plants, thereby increasing available $P A R$ at leaf level using less energy. With ongoing improvements in terms of energy efficiency and availability of photosynthesis-driving wavebands, LEDs provide potential solutions to the profitability and sustainability issues that greenhouse growers face.

Research in plant growth chambers and tissue culture laboratories has proven that LEDs are an efficient light source for plant lighting in controlled environments (Hoenecke et al., 1992; Jao and Fang, 2004; Jao et al., 2005; Nhut et al., 2000; Poudel et al., 2008; Schuerger et al., 1997; Shin et al., 2008; Tanaka et al., 1998). However, the potential of LED supplemental lighting for large-scale greenhouse operations continues to be explored. Dueck et al. (2012) compared the effect of different irradiation directions of LEDs and HPS on growth and production of greenhouse-grown tomatoes in The Netherlands. They suggested that a combination of overhead HPS and LEDs is the most promising alternative for their climate, when taking into consideration different production parameters and energy costs (lighting + heating) of using the different systems. Another experiment measured responses of photosynthesis and yield for cucumber (Cucumis sativus) grown under either a combination of LEDs $(80 \%$ red $+20 \%$ blue) within the canopy + overhead HPS or HPS only during a winter production cycle (Trouwborst et al., 2010). They reported no improvement in net crop photosynthesis and fruit production when using LEDs + HPS compared with overhead HPS only but attributed their results to low irradiance (light-limited crops) throughout the experiment, regardless of treatment.

INTRACANOPY LIGHTING. Traditionally, greenhouse production has relied on the use of overhead HID lamps for photosynthetic irradiation. However, overhead lighting tends to favor upper leaf layers to maximize light interception incident at the top of the foliar canopy. This results in mutual shading in the lower leaf canopy and thus limits the $P A R$ delivered to a crop. Intracanopy lighting helps increase the efficiency of irradiation by allowing direct lighting into the inner canopy of crop stands. It has been reported that ICL can serve as a sole source of irradiation in growth chambers for crops like cowpea [Vigna unguiculata (Frantz et al., 2000; Massa et al., 2005)] and soybean [Glycine max (Stasiak et al., 1998)]. Partial ICL also has been shown to improve productivity in greenhouse crops such as sweet pepper [Capsicum annuum (Hovi-Pekkanen et al., 2006)], cucumber (Trouwborst et al., 2010), and one tomato cultivar (Gunnlaugsson and Adalsteinsson, 2006). Another energy savings advantage of ICL is that, depending on their design, lamps can be individually energized at different vertical planes. This allows for lamps to keep pace with the growth stages of tall crops like indeterminate tomatoes.

However, a direct comparison of ICL from LEDs vs. overhead HPS lighting has not been reported for the growth and production of high-wire tomato in commercial greenhouses in the United States. Moreover, a comparison with traditional HID horticultural lighting is needed in terms of costs and performance. Therefore, the objectives of the present study were to compare high-wire tomato production with and without supplemental lighting and to evaluate two different lighting positions + sources (HPS-OHL vs. LED-ICL) on several production and energy consumption parameters.

\section{Materials and methods}
Plant materials and growing CONDITIONs. Tomato rootstock 'Maxifort' (Solanum lycopersicum $\times$ S. habrochaites) and scions 'Komeett' and 'Success' (De Ruiter Seeds, Co- lumbus, $\mathrm{OH}$ ) were sown into 17-cell

seedling trays of Agrifoam soilless plugs $(5 \times 2.5 \mathrm{~cm}$, SteadyGROWpro; Syndicate Sales, Kokomo, IN) on 27 Dec. 2011 and placed in a glassglazed greenhouse in West Lafayette, IN (lat. $40^{\circ} \mathrm{N}$, long. $86^{\circ} \mathrm{W}$; U.S. Department of Agriculture hardiness zone $5 \mathrm{~b}$ ). Once the cotyledons had expanded fully, supplemental lighting of $60 \mu \mathrm{mol} \cdot \mathrm{m}^{-2} \cdot \mathrm{s}^{-1}$ from an HPS lamp was provided daily for $18 \mathrm{~h}$. All seedlings were irrigated as necessary with acidified water supplemented with a combination of two watersoluble fertilizers (3:1 mixture of $15 \mathrm{~N}-2.2 \mathrm{P}-12.5 \mathrm{~K}$ and $21 \mathrm{~N}-2.2 \mathrm{P}-$ $16.6 \mathrm{~K}$, respectively; Scotts, Marysville, $\mathrm{OH}$ ) to provide the following (in milligrams per liter): 200 nitrogen, 26 phosphorus, 163 potassium, 50 calcium, 20 magnesium, 1.0 iron, 0.5 manganese, 0.5 zinc, 0.24 copper, 0.24 boron, and 0.1 molybdenum. Scion seedlings were grafted onto a rootstock on 11 Jan. 2012 and allowed to heal. On 25 Jan. 2012, grafted seedlings were randomly selected for each lighting treatment and transplanted into rooting blocks $(4 \times$ $4 \times 2.5 \mathrm{~cm}$, SteadyGROWpro; Syndicate Sales), which were then placed into wetted coir slabs $(90 \times 15 \times 8 \mathrm{~cm}$; Coco Agro, Veyangoda, Sri Lanka). Slabs were placed on top of custommade steel gutters $(9.8 \mathrm{~m} \times 25 \mathrm{~cm}$; FormFlex Horticultural Systems, Beamsville, ON, Canada). Following transplant, plants were pinched at the axillary bud to induce doubleheading at a density of $2.3 \mathrm{stems} / \mathrm{m}^{2}$ in the production system. Plants were irrigated daily throughout the five-month experiment with a commercial complete fertilizer mix (4.5N-14P-34K; CropKing, Lodi, $\mathrm{OH}$ ) providing a $30 \%$ leaching fraction (LF). Irrigation frequency was adjusted as necessary depending on the LF. Water was treated with 93\% sulfuric acid (Brenntag, Reading, PA) at $0.08 \mathrm{~mL} \cdot \mathrm{L}^{-1}$ to reduce alkalinity to $100 \mathrm{~mL} \cdot \mathrm{L}^{-1}$ and a $\mathrm{pH}$ range of 6.0 to 6.2. Average ambient day and night temperatures of the greenhouse were set at 27 and $18{ }^{\circ} \mathrm{C}$, respectively.

Lighting treatments. The greenhouse was divided into six halfrow sections $(3.7 \times 4.9 \mathrm{~m})$ of different lighting treatments running in an east-to-west direction (Fig. 1). Each section was separated by one layer of 6-mil-thick black polyethylene plastic between two layers of white plastic 


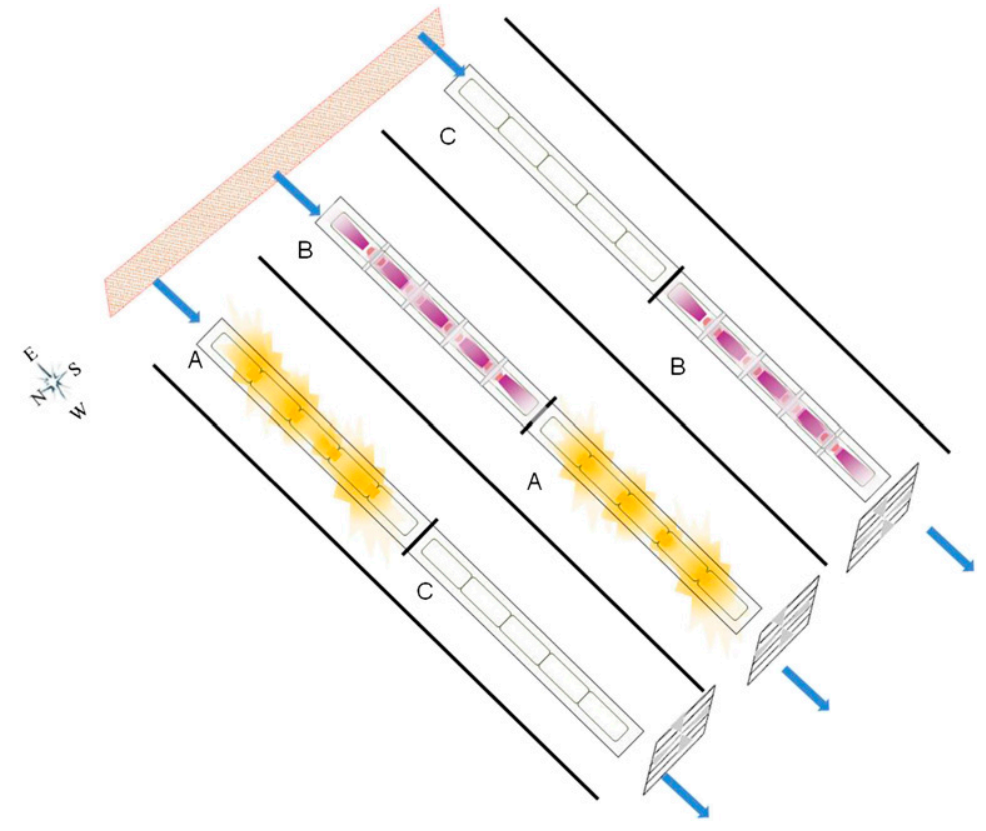

Fig. 1. Schematic representation of the experimental greenhouse showing six halfrow sections of different lighting treatments running in an east-to-west direction. Each section was separated by a white plastic curtain (bold black lines) hanging from the upper frame of the greenhouse structure and running the entire length of the rows. Short sections of plastic curtain hung perpendicular at the halfway point of each row separate different lighting treatments. Each half-row section represents one replicate of a treatment lighting eight double-headed, grafted treatment plants (four 'Komeett' /'Maxifort' and four 'Success' /'Maxifort') and one nongrafted, double-headed nontreatment plant at each section border (guard plant). The lighting treatments included (A) four 1000-W high-pressure sodium lamps emitting yellow light from above, (B) four intracanopy light-emitting diode towers emitting purple light in both directions along the row, and $(\mathrm{C})$ control treatments receiving no supplemental lighting.

(curtains) hanging from the upper frame of the greenhouse structure $(\approx 3.6 \mathrm{~m}$ from the top to the floor). The plastic curtains were used to avoid light pollution between lighting treatments and hung parallel to the rows. Short sections of plastic curtain hung perpendicular at the halfway point of each row separating different lighting treatments. Each half-row section was one replicate of a treatment, lighting eight doubleheaded, grafted treatment plants (four 'Komeett' /'Maxifort' and four 'Success' /'Maxifort') and one nongrafted, double-headed nontreatment plant at each section border (guard plant).

The lighting treatments were started on 28 Jan. 2012. Supplemental lighting treatments were kept at an average daily light integral of $9 \mathrm{~mol} \cdot \mathrm{m}^{-2} \cdot \mathrm{d}^{-1}$ from either $1000-\mathrm{W}$ HPS-OH lamps or LED-ICL towers programmed to mix 95\% red (peak wavelength at $627 \mathrm{~nm}$ ) and $5 \%$ blue (peak wavelength at $450 \mathrm{~nm}$ ) light
(Fig. 2). Each 2.5-m-tall LED tower supported three rectangular, vertically movable $0.60 \times 0.12$-m LED zones that were separately controlled (Fig. 3). Each rectangular LED zone has opposite lighting panels for irradiation in both directions within a row, each containing four red and one blue, dimmable LED strips with 12 LEDs mounted vertically within each strip. Towers were air-cooled via hollow internal tubes and fans that drew greenhouse air into the center of each tower and exhausted heat either above the canopy (during the cooling season) or below the canopy (during the heating season). A control treatment was also included for which no supplemental lighting was provided.

Before starting the experiment, a light map was developed at three heights in the greenhouse to determine the maximum photosynthetic photon flux $(P P F)$ for each lamp type (in the dark). The measured heights corresponded to the center of each vertical LED panel in a tower.

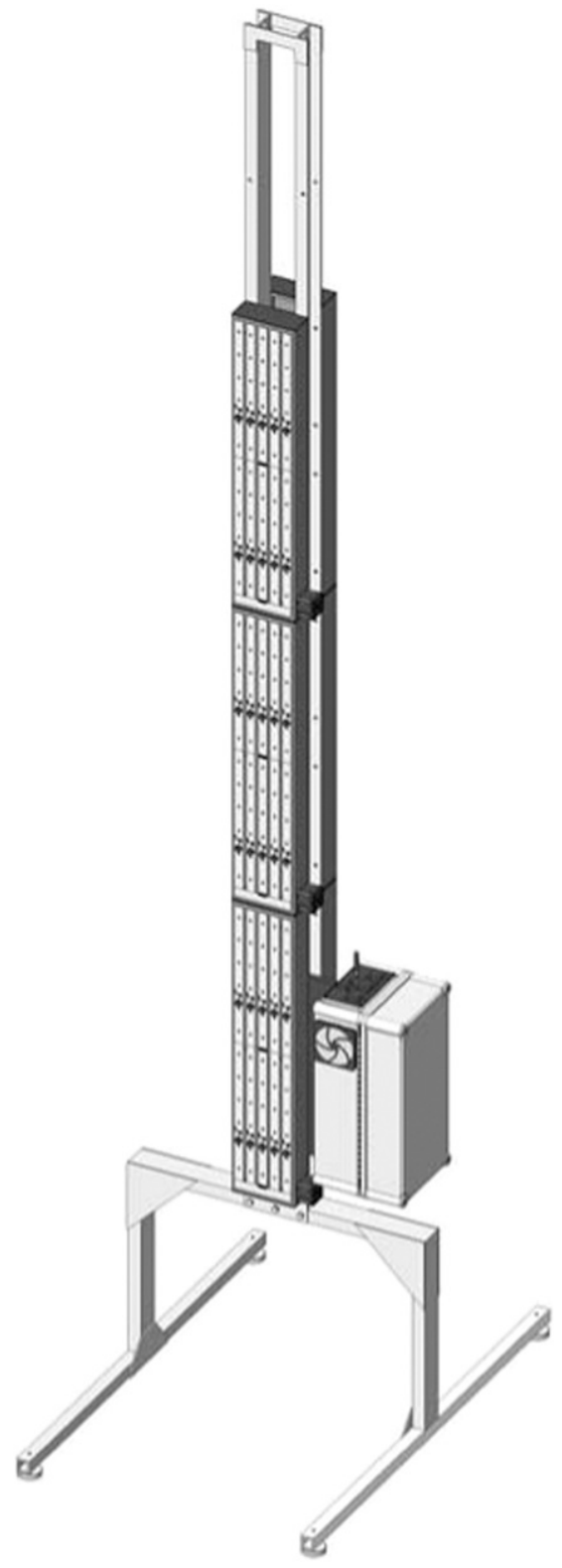

Fig. 2. Schematic representation of an intracanopy light-emitting diode (LED) tower indicating row-straddling supports, three vertically movable LED panels on each side within a row, and room at the top of the mount to move all three LED panels up by one panel equivalent. Power supply, individual panel switches, and dimming controls for each color of LED are located on the lower right.

Measurements were taken in the space where a plant will be. Because of differences in light distribution and direction from the lamps, a global $P P F$ was used to represent the $P P F$ around a given point. Global PPFs were determined at each point by calculating the sum of four measurements taken from rotating the sensor 
four times at $90^{\circ}$ (the base point directly facing the lamp) and dividing by two (Frantz et al., 1998). The output of supplemental $P P F$ was calibrated to be equivalent for both treatments using a line quantum meter (MQ-303; Apogee Instruments, Logan, UT) calibrated against a spectroradiometer (Stellar Net EPP2000, Apogee Instruments).

Kilowatt-hours of energy consumed were monitored using a builtin datalogger in every LED tower, and an energy monitor (e2 classic 2.0; Efergy U.S.A., Miami, FL) was used for groups of four HPS lamps. Removal of lower leaves and plant leaning and lowering was conducted as needed. Fruits were pruned to four per cluster (to maintain fruit grade/size uniformity) and were harvested twice weekly when the point fruit was at maturation stage 6 . Fruit FW and FN were recorded immediately following harvest. On experiment termination, number of nodes per plant was recorded. Data were analyzed as a randomized complete block design using analysis of variance and the general linear model procedure of SAS (version 9.2; SAS Institute, Cary, NC).

\section{Results and discussion}

The two commercial tomato cultivars evaluated responded similarly to the lighting treatments, so data were pooled and averaged across cultivars. Supplemental lighting induced early fruit production compared with unsupplemented controls $(26 \mathrm{~d}$ earlier for HPS-OHL and $24 \mathrm{~d}$ earlier for LEDICL) (Table 1). Node number, FN, and total fruit FW also increased in response to supplemental lighting. However, no differences were observed between the two supplemental lighting sources for any harvest parameter.

The energy consumption metrics indicated energy savings using LEDICL supplemental lighting technology relative to HPS-OHL technology (Table 2). Average daily energy consumption for the HPS-OHL treatment $(2$ reps $\times 4$ lamps) was 129 $\mathrm{kWh}$ per day, which was significantly higher than the average $31 \mathrm{kWh}$ per day consumed for the LED-ICL treatment $(2$ reps $\times 4$ towers $)$. Results for kilowatthours per gram of fruit FW indicated that the electrical conversion efficiency of LED-ICL into fruit biomass was $75 \%$ higher than that for HPS-OHL. Thus, the lighting
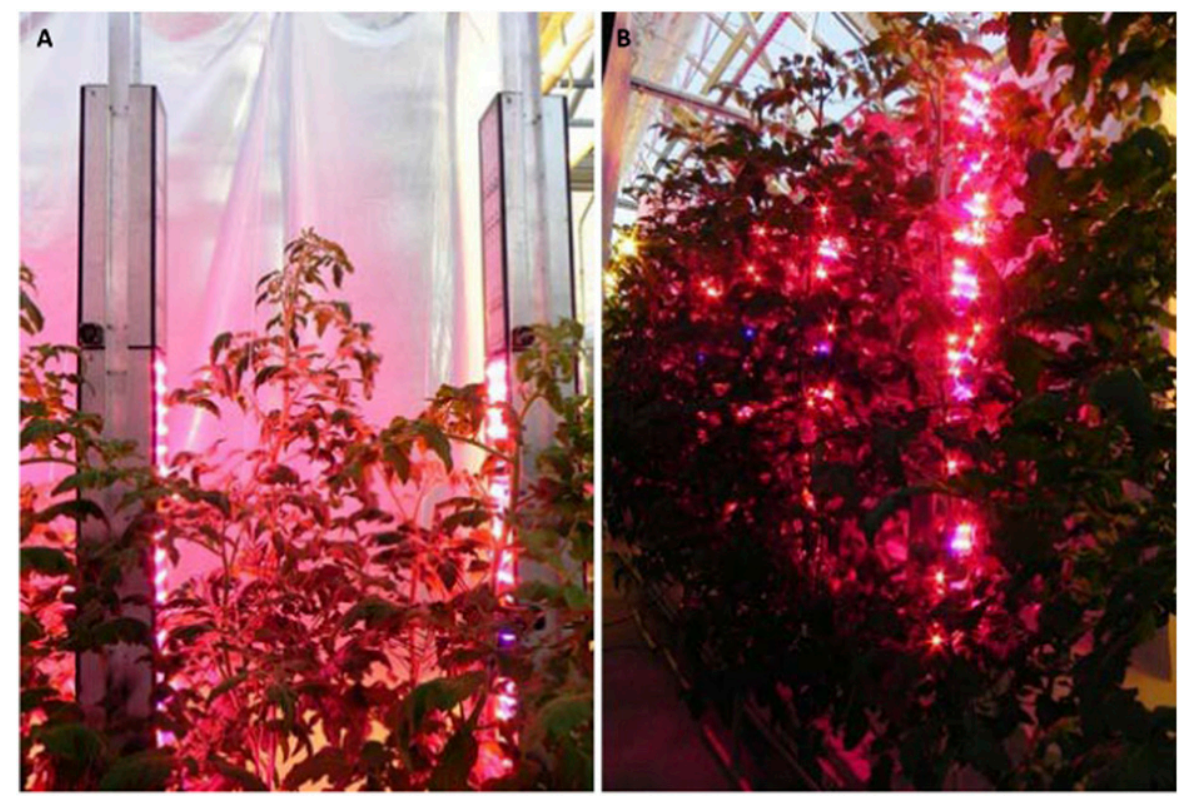

Fig. 3. (A) Two intracanopy light-emitting diode (LED) towers providing two-way supplemental lighting with two tomato plants growing between towers. Note that the upper panel was switched off because most of the plants had not yet reached the height of the panel. (B) Side view of a half-row section with plants growing in the LED treatment.

Table 1. Harvest and growth parameters per plant for tomatoes grown in a greenhouse under one of three lighting treatments for 5 mo. ${ }^{\mathrm{z}}$

\begin{tabular}{lcccc}
\hline $\begin{array}{l}\text { Lighting } \\
\text { treatments }\end{array}$ & $\begin{array}{c}\text { Harvest } \\
\text { period (d) }\end{array}$ & Nodes (no.) & $\begin{array}{c}\text { Fruit } \\
\text { harvested (no.) }\end{array}$ & $\begin{array}{c}\text { Total fruit fresh } \\
\text { wt }(\mathbf{g})^{\mathbf{x}}\end{array}$ \\
\hline HPS-OHL & $68 \mathrm{a}^{\mathrm{w}}$ & $46 \mathrm{a}$ & $97 \mathrm{a}$ & $14,159 \mathrm{a}$ \\
LED-ICL & $66 \mathrm{a}$ & $45 \mathrm{a}$ & $94 \mathrm{a}$ & $13,406 \mathrm{a}$ \\
Control & $44 \mathrm{~b}$ & $35 \mathrm{~b}$ & $67 \mathrm{~b}$ & $9,067 \mathrm{~b}$ \\
\hline
\end{tabular}

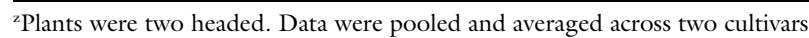

${ }^{y}$ Treatments were initiated on 28 Jan. 2012 and ended on 28 June 2012; HPS-OHL = high-pressure sodium overhead lighting, LED-ICL $=$ light-emitting diode intracanopy lighting.

${ }^{\mathrm{x}} \mathrm{l} \mathrm{g}=0.0353 \mathrm{oz}$.

${ }^{\text {w}}$ Means within columns followed by the same letter are not significantly different based on the least significant difference test $(P \leq 0.05)$.

Table 2. Electrical energy consumption, cost, and yield parameters for tomatoes grown in a greenhouse under one of three lighting treatments for 5 mo. $^{\mathrm{z}}$

\begin{tabular}{|c|c|c|c|}
\hline Crop parameters & Control & HPS-OHL & LED-ICL $^{\mathrm{y}}$ \\
\hline Energy consumption per day (kWh) & - & $129 \mathrm{a}^{\mathrm{x}}$ & $31 \mathrm{~b}$ \\
\hline Total energy consumption (kWh) & - & 19,578 & 4,697 \\
\hline Energy consumption per plant (kWh) & - & 1,224 & 294 \\
\hline Total fruit fresh weight per plant $(\mathrm{g})^{\mathrm{w}}$ & $9,067.10 \mathrm{~b}$ & $14,159.30 \mathrm{a}$ & $13,406.00 \mathrm{a}$ \\
\hline $\begin{array}{l}\text { Energy consumption } \\
\text { per fruit FW }(\mathrm{kWh} / \mathrm{g})^{\mathrm{w}}\end{array}$ & - & 0.08 & 0.02 \\
\hline Cost of electricity $(\$ / \mathrm{kWh})^{\mathrm{v}}$ & - & 0.05 & 0.05 \\
\hline Cost of electricity ( $\$ / \mathrm{g}$ of fruit $)^{\mathrm{w}}$ & - & 0.004 & 0.001 \\
\hline Average fruit fresh weight $(\mathrm{g})$ & $136.00 \mathrm{a}$ & $144.90 \mathrm{a}$ & $142.04 \mathrm{a}$ \\
\hline Lighting cost ( $\$ /$ fruit $)$ & - & 0.58 & 0.15 \\
\hline Lighting cost (\$/plant) & 一 & 61.18 & 14.68 \\
\hline
\end{tabular}

${ }^{2}$ Plants were two headed. Data were pooled and averaged across two cultivars.

${ }^{y}$ Treatments were initiated on $28 \mathrm{Jan} .2012$ and ended on 28 June 2012; HPS-OHL = high-pressure sodium overhead lighting, LED-ICL = light-emitting diode intracanopy lighting.

${ }^{x}$ Means within columns followed by the same letter are not significantly different based on the least significant difference test $(P \leq 0.05)$.

${ }^{\mathrm{w}} \mathrm{l} \mathrm{g}=0.0353 \mathrm{oz}, \mathrm{l} \mathrm{kWh} / \mathrm{g}=28.3495 \mathrm{kWh} / \mathrm{oz}$

${ }^{\mathrm{v}}$ Average electrical energy cost for Indiana during 2012. 
cost per average-sized fruit grown under the HPS-OH lamps was 403\% higher than that of using the LEDICL towers.

The improvement in production efficiency using ICL is supported by Frantz et al. (1998), who reported that cowpea grown with ICL yielded $50 \%$ of the edible biomass of plants grown under OHL while consuming only $10 \%$ as much electrical energy. Massa et al. (2005) also reported electrical utilization efficiency and inner-canopy leaf retention for intracanopy-grown cowpea compared with that of overheadlighted plants. A greenhouse study showed that $25 \% \mathrm{ICL}+75 \% \mathrm{OHL}$ increased FW and FN, fruit size, and percentage of first-class fruit for cucumber while reducing energy consumption compared with OHL (Hovi-Pekkanen et al., 2006). More recently, Trouwborst et al. (2010) reported that ICL did not increase yield for cucumber but attributed their results to limiting light intensities in the greenhouse. Although our results did not show an increase in yield from using the ICL, they do indicate significant energy savings without compromising yield. Also, our results show that ICL from LEDs alone resulted in equivalent yield to OHL from HPS alone. Thus, hybrid OHL from HPS + ICL from dense arrays of high-output LEDs would not be required to maintain equivalent yields in our experimental setup.

\section{Conclusions}

Results of this technology comparison and experiment, in addition to furthering scientific and practical understanding of the impact of LED lighting on plant growth and development for tomato, also demonstrate that LED-ICL is a viable alternative to HPS-OHL. LEDs are a potential solution toward the goal of enhancing the profitability and sustainability of the greenhouse industry. Additional research is needed to demonstrate the applicability of this technology on the production of other greenhouse crops.

\section{Literature cited}

Bourget, C.M. 2008. An introduction to light emitting diodes. HortScience 43:1944-1946.
Brault, D., C. Gueymard, R. Boily, and A. Gosselin. 1989. Contribution of HPS lighting to the heating requirements of a greenhouse. Amer. Soc. Agr. Eng. 89(4039)

Cathey, H.M. and L.E. Campbell. 1977. Plant productivity: New approaches to efficient sources and environmental control. Trans. Amer. Soc. Agr. Eng. 20:360366.

Cook, R. and L. Calvin. 2005. Greenhouse tomatoes change the dynamics of the North American fresh tomato industry. 13 May 2011. <http://postharvest. ucdavis.edu/datastorefiles /2 34-447. pdf $>$.

Dorais, M., A. Gosselin, and M.J. Trudel. 1991. Annual greenhouse tomato production under a sequential intercropping system using supplemental light. Sci. Hort. 45:225-234.

Dueck, T.A., J. Janse, B.A. Eveleens, F.L.K. Kempkes, and L.F.M. Marcelis. 2012. Growth of tomatoes under hybrid LED and HPS lighting systems. Acta Hort. 952:335-342.

Frantz, J.M., C. Chun, R.J. Joly, and C.A. Mitchell. 1998. Intracanopy lighting of cowpea canopies in controlled environments. Life Support Biosph. Sci. 5:183190.

Frantz, J.M., B. Hand, L. Buckingham, and S. Ghos. 2010. Virtual grower: Software to calculate heating costs of greenhouse production in the United States. HortTechnology 20:778-785.

Frantz, J.M., R.J. Joly, and C.A. Mitchell. 2000. Intracanopy lighting influences radiation capture, productivity, and leaf senescence in cowpea canopies. J. Amer. Soc. Hort. Sci. 125: 694-701.

Greer, L. and S. Diver. 2000. Organic greenhouse vegetable production. 13 May 2011. <http://www.attra.org/ attra-pub/PDF/ghveg.pdf $>$.

Gunnlaugsson, B. and S. Adalsteinsson. 2006. Interlight and plant density in year-round production of tomato at northern latitudes. Acta Hort. 711:7175 .

Hoenecke, M.E., R.J. Bula, and T.W. Tibbitts. 1992. Importance of 'blue' photon levels for lettuce seedlings grown under red-light-emitting diodes. HortScience 27:427-430.

Hovi-Pekkanen, T., J. Näkkilä, and R Tahvonen. 2006. Increasing productivity of sweet pepper with interlighting. Acta Hort. 711:165-169.

Jao, R.C. and W. Fang. 2004. Growth of potato plantlets in vitro is different when provided concurrent versus alternating red and blue light photoperiods. HortScience 39:380-382.

Jao, R.C., C. Lai, W. Fang, and S. Chang. 2005 . Effects of red light on the growth of Zantedeschia plantlets in vitro and tuber formation using light-emitting diodes. HortScience 40:436-438.

Massa, G.D., C.A. Mitchell, J.C. Emmerich, and R.C. Morrow. 2005. Development of a reconfigurable LED plant-growth lighting system for equivalent system mass reduction in an ALS. 35th Intl. Conf. Environmental Systems, Rome, Italy. SAE Technical Paper No. 200501-2955.

McAvoy, R.J. and H.W. Janes. 1984. The use of high pressure sodium lights in greenhouse tomato crop production. Acta Hort. 148:877-888.

Morrow, R.C. 2008. LED lighting in horticulture. HortScience 43:19471950.

Nelson, P.V. 2012. Greenhouse operation and management. 7th ed. PrenticeHall, Upper Saddle River, NJ.

Nhut, D.T., T. Takamura, H. Watanabe, and M. Tanaka. 2000. Light emitting diodes (LEDs) as a radiation source for micropropagation of strawberry, p. 114118 In: C. Kubota and C. Chun (eds.). Transplant production in the 21 st century. Kluwer Academic Publishers, Dordrecht, The Netherlands.

Philips Lumileds Lighting Co. 2012. LUXEON Rebel Color Portfolio. Datasheet DS68:20120421. Philips Lumileds Lighting Co., Amsterdam, The Netherlands.

Poudel, P.R., I. Kataoka, and M. Moshioka. 2008. Effect of red-and blue-light-emitting diodes on growth and morphogenesis of grapes. Plant Cell Tissue Organ Cult. 92:147-153.

Rodriguez, B.R. and V.N. Lambeth. 1975. Artificial lighting and spacing as photosynthetic and yield factors in winter greenhouse tomato culture. J. Amer. Soc. Hort. Sci. 100:694-697.

Schuerger, A.C., C.S. Brown, and E.C. Stryjewski. 1997. Anatomical features of pepper plants (Capsicum annuum L.) grown under red light-emitting diodes supplemented with blue or farred light. Ann. Bot. (Lond.) 79:273282

Shin, K.S., N. Murthy, J.W. Heo, E.J. Hahn, and K.Y. Paek. 2008. The effect of light quality on the growth and development of in vitro cultured Doritaenopsis plants. Acta Physiol. Plant. 30:339343. 


\section{Research Reports}

Stasiak, M.A., R. Cote, M. Dixon, and B. Grodzinski. 1998. Increasing plant productivity in closed environments with inner canopy illumination. Life Support Biosph. Sci. 5:175-182.

Tanaka, M., T. Takamura, H. Watanabe, M. Endo, T. Yanagi, and K. Okamoto. 1998. In vitro growth of Cymbidium plantlets cultured under super red and blue light-emitting diodes (LEDs). J. Hort. Sci. Biotechnol. 73:39-44.

Tibbitts, T.W., D.C. Morgan, and I.J Warrington. 1987. Growth of lettuce, spinach, mustard, and wheat plants under four combinations of high pressure sodium, metal halide and tungsten halogen lamps at equal PPFD. J. Amer. Soc. Hort. Sci. 108:622-630.

Trouwborst, G., J. Oosterkamp, S.W. Hogewoning, J. Harbinson, and W. van Ieperen. 2010. The responses of light interception, photosynthesis and fruit yield of cucumber to LED-lighting within the canopy. Physiol. Plant. 138:289-300. 